\title{
EU-COUNTRY AND NON-EU-COUNTRY AT THE TIME OF CRISIS: FOREIGN DIRECT INVESTMENT*
}

\author{
Helga Kristjánsdóttir ${ }^{1}$, Stefanía Óskarsdóttir²
}

\begin{abstract}
The global financial crisis affected the flows of foreign direct investment (FDI). This study focuses on two countries in the midst of the financial crisis: Iceland with IMF backup, and Ireland with ECB backup. The research focus is on the situation from the broad perspective of international economics and political atmosphere, combining government decisions with economic consequences. We analyze inward foreign direct investment, incorporating factors like economic size and stock market firms, receiving portfolio investment, rather than FDI. Our findings indicate that before the crisis the economic wealth in the domestic market to have positive effects on FDI, and firms receiving portfolio investment on the stock market are competing with FDI. This is the case for both Ireland and Iceland. However, after the crisis, these factors have insignificant impact on FDI.
\end{abstract}

Key words: European Union, EFTA, Ireland, Iceland, Global Financial Crisis, International Trade, Foreign Direct Investment (FDI).

JEL Classifications: F14, F21, F23

\section{Introduction}

"The song of Ice and Ire" was the International Monetary Fund (2020) presentation title by the Nobel Prize winner Paul Krugman (2011), discussing the European Union (2020), the European Central Bank (2020), the International Monetary Fund (2018), as well as the EU-country Ireland (European Union, 2020), and the NON-EU-country Iceland (European Free Trade Association, 2020).

At the time of the economic crash, Ireland had the Euro - but Iceland did not. Ireland had the European Central Bank (ECB) as the lender of last resort, and Iceland sought help from the International Monetary Fund (IMF Survey, 2015). During the crisis, public debt in Iceland surged up to $95 \%$ of GDP, and IMF imposed capital controls in Iceland providing an intensive rescue program "The IMF-supported program of $\$ 2.1$ billion remains among the largest relative to the size of the economy - 18 percent of Iceland's GDP, or 1,190 percent of Iceland's quota in the IMF" (International Monetary Fund, 2018). How much did the backing of the ECB and the IMF matter in putting Ireland and Iceland on the path of recovery? Does it add legitimacy that helps with political stability, or at least the perception of it? This current research seeks to answer these questions along the lines of previous research (Davies and Kristjánsdóttir, 2010; Davies, Ionascu and Kristjánsdóttir, 2008). The objective of this research is to focus on the impact of the financial crisis on Iceland and Ireland, Ireland with ECB backup, and Iceland with IMF backup. We look into the implication of the EU membership, considering Ireland and Iceland. The issue of individual country endowments is also relevant in the discussion of economic recovery, which country is more attractive for foreign direct investment (FDI) as reflection on the confidence of the global economic and political community in the countries; we measure FDI to the two countries applying trade modelling (Bergstrand 1985; Carr Markusen and Maskus 2001; Markusen 2004).

Two economies went through extreme economic crashes (International Monetary Fund, 2018), being no strangers to difficult economic conditions throughout history. This has tested their tolerance and shaped their cultures (Hofstede, 1980, 2001; Kristjánsdóttir, 2016a, 2019a, 2020; Kristjánsdóttir, Guðlaugsson, Guðmundsdóttir and Aðalsteinsson, 2017, 2020) accounted for empirically in this research. After World

Corresponding author:

${ }^{1}$ Faculty of Business Administration, University of Akureyri, Iceland.

E-mail: helga@unak.is

ORCID: https://orcid.org/0000-0002-8857-8063

${ }^{2}$ Faculty of Political Science, University of Iceland, Iceland.

E-mail: stefosk@hi.is

ORCID: https://orcid.org/0000-0003-3554-1512

\footnotetext{
* Paul Krugman presentation during IMF conference in Iceland provided incentive for this research. Helpful comments received on IMF conference in Iceland are highly appreciated
} 
War I and World War II, Iceland and Ireland have remained primarily based economies with limited economic diversification, relying on agriculture and fisheries. FDI has not been a significant factor for either country for very long. Measurement only started in the 1970s (IMF, 2016), giving a chance to explore a maturing market from birth to present. Small economies like these are only in few different sectors (Krugman, 2011), so it is easier to get a picture on what the major economic players are for each country.

Iceland is geographically more distant (Distance Calculator, 2020) from the European mainland, and distances itself more by not having the EU membership or the Euro. The last fact may actually have helped Iceland in adjusting itself better to the current economic situation. Our data account for the EU membership, and we seek to analyze whether the EU or non-EU membership affect the way these countries tackle crisis.

This paper focuses on Iceland and Ireland, providing analysis on the impact of the financial crisis. Both have small domestic markets and are therefore highly dependent on foreign trade and investment, Ireland has EU membership, Iceland is not a member country. Has the EU turned out to be a partnership for success, helping countries in their time of need, or is it imposing needlessly harsh rules that in actuality restrict the ability of a struggling nation to find its own way back to prosperity?

Now that we have established some potential factors for research, the question becomes, how did the global economic crisis affect FDI in two different countries? To answer that, the analysis includes variables accounting for political instability and government reaction (Kristjánsdóttir, 2016b). How did these countries work it out, and what might come next? What can we take away from the experience of these countries in the past decade, which can be used to make a more informed decision about the future?

We study FDI in Ireland and Iceland, considering (Everett, Kelly and Mccann, 2015; Blonigen, Davies, and Waddell, 2007) finding conventional explanation for FDI and spatial interdependence to be affected by the choice of sample countries. Our application of data in the model is similar to Davies (2008). Earlier studies indicate that FDI flows from the United States increased as result of the formation of the European Community. Some recent studies give mixed results (Hoeller, Girouard and Colecchia, 1998).

\section{Model Setup}

Our estimation for Iceland and Ireland involves usage of other variables, introduced in Table 1.

\section{Data}

Total of 25 European countries are accounted for in this current research, these are: Austria, Belgium, the Czech Republic, Denmark, Estonia, Finland, France, Germany, Greece, Hungary, Iceland, Ireland, Israel, Italy, Luxembourg, the Netherlands, Norway, Poland, Portugal, the Slovak Republic, Slovenia, Spain, Sweden, Switzerland, the United Kingdom.

Data runs from 1990 through 2010, and covers investment from individual countries to Iceland and Ireland in particular years. We apply foreign direct investment, inward position (FDI) data from OECD (2020). These are FDI series of BOP and IIP aggregates, inward position at year-end in millions USD. The FDI data application here is in similar manner as data application in previous research (Kristjánsdóttir, 2010, 2012b, 2013, 2017, 2019b).

Foreign direct investment, net inflows (BoP, current USD). Obtained from World Bank (2020). Foreign direct investment are the net inflows of investment to acquire a lasting management interest (10 percent or more of voting stock) in an enterprise operating in an economy other than that of the investor. It is the sum of equity capital, reinvestment of earnings, other long-term capital, and short-term capital as shown in the balance of payments. This series shows net inflows

Table 1

\section{Variable Definition}

\begin{tabular}{|c|c|}
\hline FDI stock $\mathrm{j}_{\mathrm{j}, \mathrm{t}}$ & $\begin{array}{l}\text { FDI series of BOP and IIP aggregates. Inward position at year-end USD, millions in host country }(\mathrm{j}) \text {, over time }(\mathrm{t}) \text {. } \\
\text { OECD }(2020) \text {. }\end{array}$ \\
\hline Portfolio equity ${ }_{j, t}$ & $\begin{array}{l}\text { Portfolio equity, net inflows (BoP, current US\$): } \\
\text { Portfolio equity includes net inflows from equity securities other than those recorded as direct investment and including } \\
\text { shares, stocks, depository receipts (American or global), and direct purchases of shares in local stock markets by foreign } \\
\text { investors. Data are in current USD. World Bank (2020). }\end{array}$ \\
\hline trade $_{j, t}$ & Merchandise trade (\% of GDP). World Bank (2020). \\
\hline nr of firms $\mathrm{j,t}$ & Listed domestic companies on the host country stock market, total. World Bank (2020). \\
\hline $\mathrm{GDP}_{\mathrm{j}, \mathrm{t}}$ & Gross domestic product (GDP) current USD, in host country $(\mathrm{j})$. Running over time $(\mathrm{t})$. World Bank (2020). \\
\hline gov pol $_{j, t}$ & $\begin{array}{l}\text { Adaptability of government policy to changes in the economy is high (IMD WCY executive survey based on an index } \\
\text { from } 0 \text { to } 10 \text { ). IMD (2020). }\end{array}$ \\
\hline trans ${ }_{j, t}$ & $\begin{array}{l}\text { Transparency of government policy is satisfactory (Updated: May 2011, IMD WCY executive survey based on an index } \\
\text { from } 0 \text { to 10). IMD (2020). }\end{array}$ \\
\hline risk premium ${ }_{\mathrm{j}, \mathrm{t}}$ & Risk premium on lending (lending rate minus treasury bill rate, \%). World Bank (2020). \\
\hline
\end{tabular}


(new investment inflows less disinvestment) in the reporting economy from foreign investors. Data are in current USD.

Portfolio equity, net inflows (BoP, current USD) are obtained from World Bank (2019). Portfolio equity includes net inflows from equity securities other than those recorded as direct investment and including shares, stocks, depository receipts (American or global), and direct purchases of shares in local stock markets by foreign investors. Data are in current USD.

Merchandise trade (percentage of GDP). Merchandise trade as a share of GDP is the sum of merchandise exports and imports divided by the value of GDP, all in current USD World Bank (2020).

Listed domestic companies are the domestically incorporated companies listed on the country's stock exchanges at the end of the year. This indicator does not include investment companies, mutual funds, or other collective investment vehicles. Data is from the World Bank (2020).

Risk premium on lending (lending rate minus Treasury bill rate, \%). Risk premium on lending is the interest rate charged by banks on loans to private sector customers minus the "risk free" Treasury bill interest rate at which short-term government securities are issued or traded in the market. In some countries this spread may be negative, indicating that the market considers its best corporate clients to be lower risk than the government. The terms and conditions attached to lending rates differ by country, however, limiting their comparability. Risk premium data is from the World Bank (2020) not reported by the following countries: Austria, Denmark, Estonia,
Finland, Luxembourg, Norway, and the Slovak Republic.

Adaptability of government policy to changes in the economy is high (IMD WCY executive survey based on an index from zero to 10), IMD data (2020).

Transparency of government policy is satisfactory (IMD WCY executive survey based on an index from zero to 10), IMD data (2020).

The data on the gross domestic product (GDP) measure comes from the World Bank (2020). Gross domestic product reported in GDP current USD.

\section{Regression results}

We present regression results in Table 2 for both Iceland and Ireland before and after the crisis.

1990-2007 ICELAND estimates: GDP has significant positive effects on FDI stock, as well as transparency of government policy. However, it is significantly negatively affected by the number of firms and the risk premium. Trade and government policy do not have significant effects on FDI.

2008-2010 ICELAND estimates: Trade, number of firms, GDP, government policy, transparency, and risk premium do not significantly affect FDI.

1990-2007 IRELAND estimates: GDP has positive effects on FDI. Number of firms has negative effects on FDI stocks. However, trade, government policy, transparency of government policy, and risk premium do not have significant effects on FDI.

2008-2010 IRELAND estimates: Trade, number of firms, GDP, government policy, transparency, and risk premium do not have significant effects on FDI.

Table 2

Determinants of FDI in Iceland and Ireland

\begin{tabular}{|c|c|c|c|c|}
\hline & 1990-2007 ICELAND & 2008-2010 ICELAND & 1990-2007 IRELAND & 2008-2010 IRELAND \\
\hline Regressors & FDI stock $\mathrm{i}_{\mathrm{j}, \mathrm{t}}$ & FDI stock ${ }_{j, t}$ & FDI stock $_{\mathrm{j}, \mathrm{t}}$ & FDI stock $_{\mathrm{i}, \mathrm{t}}$ \\
\hline trade $_{j, t}$ & $\begin{array}{c}0.32 \\
(0.98)\end{array}$ & $\begin{array}{c}0.22 \\
(0.28)\end{array}$ & $\begin{array}{c}-9.62 \\
(-0.72)\end{array}$ & $\begin{array}{c}-8.13 \\
(-0.16)\end{array}$ \\
\hline nr of firms $j, t$ & $\begin{array}{c}-0.06^{* * *} \\
(-3.40) \\
\end{array}$ & $\begin{array}{c}0.06 \\
(1.17)\end{array}$ & $\begin{array}{c}-1.64^{*} \\
(-1.76) \\
\end{array}$ & $\begin{array}{c}-2.08 \\
(-0.66)\end{array}$ \\
\hline $\mathrm{GDP}_{\mathrm{j}, \mathrm{t}}$ & $\begin{array}{c}6.43 \mathrm{e}-11^{* * *} \\
(7.34)\end{array}$ & $\begin{array}{c}9.53 \mathrm{e}-12 \\
(0.50)\end{array}$ & $\begin{array}{c}7.84 \mathrm{e}-10^{*} \\
(1.94)\end{array}$ & $\begin{array}{c}-1.73 e-10 \\
(-0.16)\end{array}$ \\
\hline $\operatorname{gov}_{\text {pol }}, \mathrm{t}$ & $\begin{array}{l}-12.33 \\
(-0.94) \\
\end{array}$ & $\begin{array}{l}-22.50 \\
(-0.56)\end{array}$ & $\begin{array}{l}-81.91 \\
(-0.11)\end{array}$ & $\begin{array}{c}-1278.08 \\
(-0.54) \\
\end{array}$ \\
\hline $\operatorname{trans}_{j, t}$ & $\begin{array}{c}32.63^{* * *} \\
(2.94)\end{array}$ & $\begin{array}{l}46.76 \\
(1.42)\end{array}$ & $\begin{array}{l}82.55 \\
(0.16) \\
\end{array}$ & $\begin{array}{l}306.16 \\
(0.15)\end{array}$ \\
\hline risk premium $_{j, t}$ & $\begin{array}{c}-28.67^{* * *} \\
(-3.79)\end{array}$ & $\begin{array}{l}15.85 \\
(0.88)\end{array}$ & $\begin{array}{l}-42.52 \\
(-0.12)\end{array}$ & $\begin{array}{c}-1035.26 \\
(-0.92)\end{array}$ \\
\hline constant & $\begin{array}{l}-37.45 \\
(-0.62)\end{array}$ & $\begin{array}{l}-174.10 \\
(-1.31)\end{array}$ & $\begin{array}{l}890.46 \\
(0.33)\end{array}$ & $\begin{array}{c}10415.40 \\
(1.30)\end{array}$ \\
\hline R-sq & 0.734 & 0.651 & 0.088 & 0.353 \\
\hline Obs & 64 & 23 & 63 & 19 \\
\hline
\end{tabular}

Robust t-statistics reported in parentheses.

*** Significant at the 1 percent level.

** Significant at the 5 percent level.

* Significant at the 10 percent level. 


\section{Summary and conclusions}

The objective of this research is to capture how Iceland and Ireland were affected by the global financial crisis. To capture this, we analyze the foreign direct investment (FDI) going into Iceland and Ireland, before and after the crisis.

We find that only in the period before the crisis, both in Ireland and Iceland, economic wealth in the domestic market have positive effects on FDI, however the number of listed firms to have negative effects on FDI. This indicates that before the crisis, investment to go to these countries based on growth and prosperity in the economy, making them attractive to foreigners. However, after the crisis the economic slowdown makes them less feasible for foreign direct investment, making economic wealth insignificant for FDI.
Moreover, we find number of listed firms in the stock market to have negative effect on FDI before the crisis in both countries. This indicates that the more the stock market grows with portfolio investment, the less FDI, which is understandable. However, after the crisis, these effects are insignificant, and FDI is not competing with portfolio investment anymore. In addition, before the crisis GDP and transparency have positive effects for Iceland, but risk premium negative effects. After the crisis, the financial factors applied do not have any effects in either Ireland or Iceland.

Overall estimates indicate when analyzing FDI in Ireland and Iceland, there is only competition between portfolio investment and foreign direct investment before the crisis, not after. In addition, the economic wealth only made FDI attracting before the crisis, not after the crisis.

\section{References:}

Bergstrand, J. H. (1985). The Gravity Equation in International Trade: Some microeconomic Foundations and Empirical Evidence. The Review of Economics and Statistics. 67: 474-481.

Blonigen, B. A., Davies, R. B., \& Waddell, G. R. (2007). FDI in space: Spatial autoregressive relationships in foreign direct investment. European Economic Review. 51(5): 1303-1325.

Davies, R. B. (2008). Hunting High and Low for Vertical FDI. Review of International Economics. 16(2): $250-267$.

Davies, R. B., \& Kristjánsdóttir, H. (2010). Fixed Costs, Foreign Direct Investment, and Gravity with Zeros. Review of International Economics. 18(1): 47-62.

Davies, R. B., Ionascu, D., \& Kristiánsdóttir, H. (2008). Estimating the Impact of Time-Invariant Variables on FDI with Fixed Effects. Review of World Economics. 144(3): 381-407. doi: 10.1007/s10290-008-0153-0

Distance Calculator (2020). How Far is it. Available at: http://www.indo.com/distance

European Central Bank (2020). EU and euro area membership. Available at: https://www.ecb.europa.eu (downloaded February 28).

European Free Trade Association (2020). About EFTA. History. Available at: http://www.efta.int/about-efta/ history.aspx

European Union (2020). Available at: https://europa.eu/ (downloaded February 28).

Everett, M., Kelly, J. \& Mccann, F. (2015). International Banking and Liquidity Risk Transmission: Evidence from Ireland. IMF Economic Review. 63(3): 542-567.

Hoeller P., Girouard N. \& Colecchia A. (1998). The European Union's Trade Policies and Their Economic Effects. OECD Economics Department Working Papers. No. 194.

Hofstede, G. (1980). Culture's Consequences. New York: Sage.

Hofstede, G. (2001). Culture's Consequences: Comparing Values, Behaviors, Institutions, and Organizations across Nations. New York: Sage.

Hofstede, G., \& M. H. Bond (1988). The Confucius Connection: From Cultural Roots to Economic Growth. Organizational Dynamics. 16(4): 4-21.

IMD (2019). Infrastructure. IMD International. Lausanne, Switzerland.

IMF (2015). IMF and Iceland Outline \$2.1 Billion Loan Plan. IMF Survey online. Available at: https://www.imf.org/ en/News/Articles/2015/09/28/04/53/socar102408a

International Monetary Fund (1992). Regional Trade Arrangements March. Occasional Paper 93. Editors: Augusto de la Torre and Margaret R. Kelly. Washington DC.

International Monetary Fund (2011). IMF Conference Iceland's Recovery - Lessons and Challenges. Reykjavík, Iceland. Available at: http://www.imf.org/external/np/seminars/eng/2011/isl/ (Downloaded January 8, 2020).

International Monetary Fund (2016). Available at: http://www.imf.org/external/data.htm (Downloaded January 8, 2020). Kristjánsdóttir, H. (2010). Foreign Direct Investment: The Knowledge-Capital Model and a Small Country Case. Scottish Journal of Political Economy. 7(5): 591-614.

Kristjánsdóttir, H. (2012b). Exports from a Remote Developed Region: Analyzed by an Inverse Hyperbolic Sine Transformation of the Gravity Model. The World Economy. 35(7): 953-966.

Kristjánsdóttir, H. (2013). Foreign Direct Investment in a Small Open Economy. Applied Economics Letters. Taylor \& Francis. 20(15): 1423-1425. 
Kristjánsdóttir, H. (2016a). Foreign Direct Investment in the Hospitality Industry in Iceland and Norway in comparison to the Nordics and a range of other OECD countries. Scandinavian Journal of Hospitality and Tourism. 16(4): 395-403.

Kristjánsdóttir, H. (2016b). Can the Butler's Tourist Area Cycle of Evolution Be Applied to Find the Maximum Tourism Level? A Comparison of Norway and Iceland to Other OECD Countries, Scandinavian Journal of Hospitality and Tourism, 16:1, 61-75. doi: 10.1080/15022250.2015.1064325

Kristjánsdóttir, H., Guðlaugsson, P.Ö., Guðmundsdóttir, S., \& Aðalsteinsson, G. D. (2017). Hofstede National Culture and International Trade. Applied Economics. 49(57): 5792-5801. doi: 10.1080/00036846.2017.1343446. Kristjánsdóttir, H. (2017). Country Competitiveness: An Empirical Study. Baltic Region. 9(2): 31-44. doi: 10.5922/2079-8555-2017-2-3

Kristjánsdóttir, H. (2019a). Tourism in a Remote Nordic Region: Vat, Internet, Oil, English, Distance, Hofstede, and Christianity. Cogent Social Sciences. 5: 1709346.

Kristjánsdóttir, H. (2019b). Does investment replace aid as countries become more developed? Baltic Journal of Economic Studies. 5(2): 256-261. doi: 10.30525/2256-0742/2019-5-2-256-261

Kristjánsdóttir, H., Guðlaugsson, P.Ö., Guðmundsdóttir, S., \&Aðalsteinsson, G. D. (2020). Cultural and geographical distance: effects on UK exports. Applied Economics Letters. 27(4):275-279. doi: 10.1080/13504851.2019.1613495 Kristjánsdóttir, H. (2020). Tax on tourism in Europe: Does higher value-added tax (VAT) impact tourism demand in Europe? Current Issues in Tourism. doi: 10.1080/13683500.2020.1734550

International Monetary Fund (2018). Ragnarök: Iceland's Crisis, its Successful Stabilization Program, and the Role of the IMF. Poul M. Thomsen, Director, European Department, International Monetary Fund. Harpa Conference Center, Reykjavik. Available at: https://www.imf.org/en/News/Articles/2018/09/15/sp091518-ragnarokiceland-s-crisis-its-successful-stabilization-program-and-the-role-of-the-imf

International Monetary Fund (2020). Available at: https://www.imf.org/en/Countries/ISL

Krugman, P. (1991). Increasing Returns and Economic Geography. The Journal of Political Economy. 99(3): 483-499. Krugman P. (2011). A Song of Ice and Ire: Iceland in context. Presentation at the IMF Conference Iceland's Recovery-Lessons and Challenges, Reykjavík, Iceland. Available at: http://www.imf.org/external/np/seminars/ eng/2011/isl/ (Downloaded January 8, 2020).

Luenen, C. (2010). The Coming Three-Bloc World. Political Insight. 1(3):98-100.

Markusen, J. R. (2004). Multinational Firms and the Theory of International Trade. MIT Press, Cambridge, Mass.

Markusen, J. R., Venables, A. J., Konan E., \& K. H. Zhang (1996). A unified Treatment of Horizontal Direct Investment and the Pattern of Trade in Goods and Services. NBER Working Paper 5696, National Bureau of Economic Research, Cambridge MA.

Moonhawk, K. (2012). Disguised Protectionism and Linkages to the GATT/WTO. World Politics. 64(3): 426-475. OECD (2019). FDI series of BOP and IIP aggregates. Inward position at year-end. Available at: http://stats.oecd.org/ Index.aspx?DataSetCode=FDI_FLOW_PARTNER\# (Downloaded Jan 2, 2020).

Poon, J. P. H., Thompson, E. R., \& Kelly, P. F. (2004). Myth of the Triad? The Geography of Trade and Investment 'Blocs'. Transactions of the Institute of British Geographers. 25(4): 427-444.

Shankar, R. (2007). Balance Sheet Effects, Growth, and Crises. Review of International Economics. 15(4): $720-734$. Thangavelu, S. M., Yong, Y. W., \& Chongvilaivan, A. (2009). FDI, Growth and the Asian Financial Crisis: The Experience of Selected Asian Countries. World Economy. 32(10): 1461-1477.

Qian, X., \& Steiner, A. (2014). International Reserves and the Composition of Foreign Equity Investment. Review of International Economics. 22(2): 379-409.

World Bank (2019). Data. Available at: http://data.worldbank.org/indicator (Downloaded Jan 1, 2020).

Zwinkels, R. C. J., \& Beugelsdijk, S. (2010). Gravity equations: Workhorse or Trojan horse in explaining trade and FDI patterns across time and space? International Business Review. 19(1):102-115. 